) Gi rask respons på artikler gjennom artikkelens kommentarfelt på tidsskriftet.no. Respons som er postet innen én måned etter at artikkelen er publisert, vurderes for publisering som Brev til redaktøren i papirutgaven.

Redaksjonen forbeholder seg retten til å foreta redaksjonelle endringer.

Forfattere av vitenskapelige artikler har tilsvarsrett, jf. Vancouver-gruppens regler.

\section{Slurv i originalartikkelen}

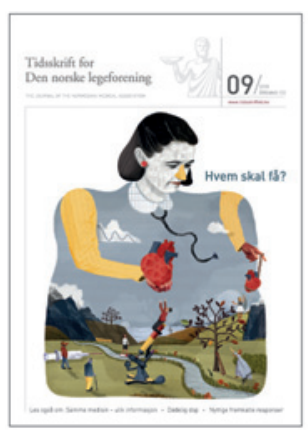

I en leder i Tidsskriftet nr. 9/2013 bruker Erlend Hem seg selv som eksempel og forteller om da han ble feilsitert (1). Hem maskerer imidlertid et alvorlig problem med sin egen artikkel, nemlig at de har angitt sine studieobjekter upresist. Hem og medarbeideres studie angir «norske leger» eller «Norwegian physicians» når man egentlig mener «leger som jobber i Norge». Det er ikke bare unøyaktig, det er faktisk feil å bruke uttrykket norske leger. Tall fra 2011 viser at nær $45 \%$ av legene som er autorisert til å jobbe i Norge, har utenlandsk statsborgerskap (2). Mange blir ikke værende her. Det forfatterne sannsynligvis mente, var «leger som arbeider i Norge» eller «physicians who work in Norway». Da er det det burde ha stått.

Dette er ikke ordkløveri, men får konsekvenser. Hadde noe liknende forekommet i Storbritannia, og man hadde skrevet «engelske leger», vil nok mange, inklusive skotske, irske og indiske leger, straks ha protestert.

Hovedsaken er at det er useriøst å skrive noe man ikke egentlig mener, uansett hvilket tema det gjelder.

Når man skriver seriøse fagartikler, bør man stå for hvert eneste ord av det man skriver, og man bør ikke skrive feil.

\section{Sandy Lunøe}

bareaasi@hotmail.com

Sandy Lunøe (f. 1938) er farmasøyt.

Ingen oppgitte interessekonflikter.

\section{Litteratur}

1. Hem E. Er $72 \%$ av norske leger deprimerte? Tidsskr Nor Legeforen 2013; 133: 929.

2. Storvik AG. Halvparten av legene utenlandske. Dagens Medisin. 24.2.2012. www.dagensmedisin.no/nyheter/halvparten-av-legene-utenlandske/ (13.6.2013).

Dette er en redigert versjon av et innlegg publisert som rask respons på nett 11.5.2013. http://tidsskriftet.no/article/3006690/

\section{E. Hem svarer:}

««Jeg er norsk læge», sa han enkelt, og mengden vek til side.» Det mest berømte sitatet som noen gang er tillagt en norsk lege, stammer fra kirurgen Jonas Fjeld i Øvre Richter Frichs romanserie. Hva mente dr. Fjeld med dette? At han var utdannet i Norge, at han arbeidet i Norge, eller at han var norsk statsborger? Ikke godt å vite, men de fleste vil nok mene at presisjonsnivået er tilstrekkelig.

Statistikk fra 2011 viser at «nær $45 \%$ av legene som er autorisert til å jobbe i Norge, har utenlandsk statsborgerskap». Tallet virker oppsiktsvekkende. Betyr det at halvparten av leger som arbeider i Norge, er utenlandske statsborgere? Selvsagt ikke. Tallet er basert på data fra Statens autorisasjonskontor for helsepersonell. Denne statistikken sier ingenting om hvor mange av de utenlandske legene som faktisk arbeider i Norge. En høy andel av dem er kun i Norge i kortvarige vikariater (1). Det er mer interessant å se på statsborgerskap for de legene som faktisk arbeider i Norge. Andelen utenlandske leger i Norge økte kraftig i 1990-årene fra et nivå rundt $2-3 \%$ av legepopulasjonen. Siden 2001 har tallet stabilisert seg på omkring $16 \%$ av leger under 67 år i Norge $(1,2)$.

\section{Erlend Hem}

erlend.hem@medisin.uio.no

Erlend Hem (f. 1970) er dr.med. og assisterende sjefredaktør i Tidsskriftet. Ingen oppgitte interessekonflikter.

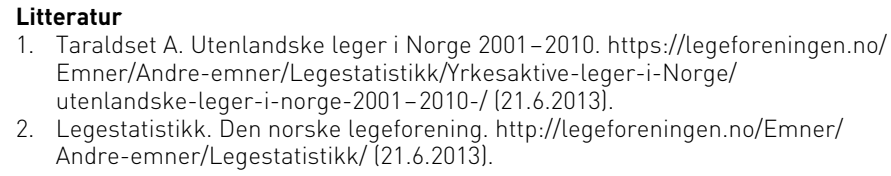

1. Taraldset A. Utenlandske leger i Norge 2001-2010. https://legeforeningen.no/ Emner/Andre-emner/Legestatistikk/Yrkesaktive-leger-i-Norge/ utenlandske-leger-i-norge-2001-2010-/ (21.6.2013).

2. Legestatistikk. Den norske legeforening. http://legeforeningen.no/Emner/ Andre-emner/Legestatistikk/ (21.6.2013). 